\title{
Medical Archives and Digital Culture: From WWI to BioShock
}

\author{
SUZANNAH BIERNOFF*
}

Keywords: BioShock; Disfigurement; Plastic Surgery; Project

Façade; Prosthetics; Henry Tonks; Visual Culture; First World War

Over the last few years my research has focused on representations of the injured body and face in First World War Britain. Some of the most intriguing cases are those in which art and medicine seem to converge or redefine each other, as in Henry Tonks' delicate pastel portraits of British servicemen with severe facial injuries, and the equally exquisite - and unsettling - prosthetic masks made by the sculptor Francis Derwent Wood for some of these patients to conceal their disfigurement when surgical reconstruction was impossible. ${ }^{1}$ In both of these examples, art could be said to ameliorate - and in different ways to aestheticise - the horrors of war, and to humanise men who had suffered what were considered at the time to be the most dehumanising of injuries. In both cases, the sources that have survived contain assumptions - often unspoken - about how, where and by whom the injured body may be seen - assumptions that have changed over time. My current project considers the afterlives of some of these documents. When we encounter medical images in art galleries or on television - or in the pages of an academic journal - what kind of cultural and imaginative work do they perform? Are there ethical considerations raised by their re-deployment or appropriation within the contexts of art and entertainment, education and academic research?

I started thinking about these questions when I discovered that case photographs from First World War medical archives had been used in the computer game BioShock. It is probably symptomatic of the game's commercial success that so few academics have heard of it. Over four million copies of the game have been sold, BioShock II was released in February 2010, and Universal Studios has plans for a film. ${ }^{2}$ Without giving the plot away, this is a spectacularly gory game, and some of the most frightening encounters are with genetic mutants known as 'splicers'. It is these sub-human monstrosities that bear

(C) Suzannah Biernoff, 2011.

* Suzannah Biernoff, Department of History of Art and Screen Media, School of Arts, Birkbeck College, University of London, 43 Gordon Square, London WC1H 0PD, UK. Email: s.biernoff@bbk.ac.uk

\footnotetext{
${ }^{1}$ Suzannah Biernoff, 'Flesh Poems: Henry Tonks and the Art of Surgery', Visual Culture in Britain, 11, 1 (2010), 25-47; Suzannah Biernoff, 'The Rhetoric of Disfigurement in First World War Britain', Social
}

History of Medicine, advance access online, 27 February 2011, doi: 10.1093/shm/hkq095.

${ }^{2}$ http://www.2kgames.com/\#/news/2k-gamesannounces-first-installment-of-bioshock-reg-2downloadable-content-now-available, accessed 8 February 2011. When Gore Verbinski - best known for directing Pirates of the Caribbean and The Ring - pulled out of the project, Universal Studios signed Spanish director Juan Carlos Fresnadillo, maker of the breathtakingly gory 28 Weeks Later. 


\section{Suzannah Biernoff}

an uncanny likeness to Tonks' portraits and the case photographs of the same men housed in the Gillies Archives at Queen Mary's Hospital in South London.

\section{'Rather Dreadful Subjects for the Public View'}

Tonks regarded his surgical studies as 'rather dreadful subjects for the public view', 3 and complained of 'all the more tedious visitors' to the hospital for whom the drawings were one of the 'sights'. ${ }^{4}$ In recent years though, the portraits have found a wider audience. They have been exhibited at the 1995 Venice Biennale, Tate Britain, the Science Museum in London, the Hunterian Museum at the Royal College of Surgeons of England, the Wellcome Collection, University College London, and the National Army Museum in Chelsea. In June 2007, the full series was made digitally available on the website of the Gillies Archives, ${ }^{5}$ and Pat Barker is writing her next novel about them. ${ }^{6}$

The photographs of Gillies' patients have entered the public domain alongside the drawings. A selection of complete case files from the Gillies Archives can be viewed online as part of the Wellcome-funded Sci-Art collaboration, Project Façade, and case photographs have featured in several recent exhibitions, including Faces of Battle at the National Army Museum, and War and Medicine at the Wellcome Collection. ${ }^{7}$ Even more than the drawings, the photographs question the limits and propriety of spectatorship. At least with the pastels, one is aware - almost physically - of Tonks' attentiveness, the quality of the artist's touch and the duration of his gaze. His authority, as an artist and surgeon, licenses our own interest. The photographs appear - even if they are not - unmediated by any aesthetic concerns: physically and psychologically naked.

As an historian of art and visual culture rather than medicine per se, I usually avoid showing the really harrowing images of facial injury and reconstructive surgery preserved in the archives. Quite apart from my own moderate squeamishness, I worry how others will respond: with pity? With disgust? Fascination? Should I name the patient, or protect his anonymity? Would he, or his relatives, want the photograph to be shown in a non-medical context? Is there a happy ending - a redemptive 'after surgery' to counterbalance the 'before'? These questions might give me pause for thought, but they generally remain unspoken. For this paper I have made an exception. The photograph in question (Figure 1) is a pre-operative record of one of Gillies' patients, who was also drawn by Tonks: Henry Ralph Lumley. It can be found quite easily on the Web, along with Lumley's case notes, a series of photographs documenting the operations, and Tonks' portrait. ${ }^{8}$ When I last checked, the pre-operative photograph

\footnotetext{
${ }^{3}$ Henry Tonks, Imperial War Museum file, item 18, 18 August 1917.

${ }^{4}$ Tonks, quoted in Joseph Hone, The Life of Henry Tonks (London: Heinemann, 1939), 128.

$5<$ http://www.gilliesarchives.org.uk/

Tonks\%20pastels/index.html>, accessed 8 February 2011.

${ }^{6}<$ http://www.readinggroupguides.com/guides_L/ life_class2.asp $>$, accessed 8 February 2011.

${ }^{7}$ Project Façade, <www.projectfacade.com $>$, accessed 26 January 2011; Faces of Battle,
}

exhibition, National Army Museum, London (November 2007-August 2008); War and Medicine, exhibition, Wellcome Collection, London (November 2009-February 2010).

${ }^{8}<$ http://www.projectfacade.com/index.php?/ case/C81/>, accessed 26 January 2011; < http://www. projectfacade.com/index.php?/galleries/comments/ lumley $>$ accessed 26 January 2011; <http://www. gilliesarchives.org.uk/Tonks\%20pastels/content/ tonks67_lumley_large.html>, accessed 26 January 2011. 


\section{Medical Archives and Digital Culture}

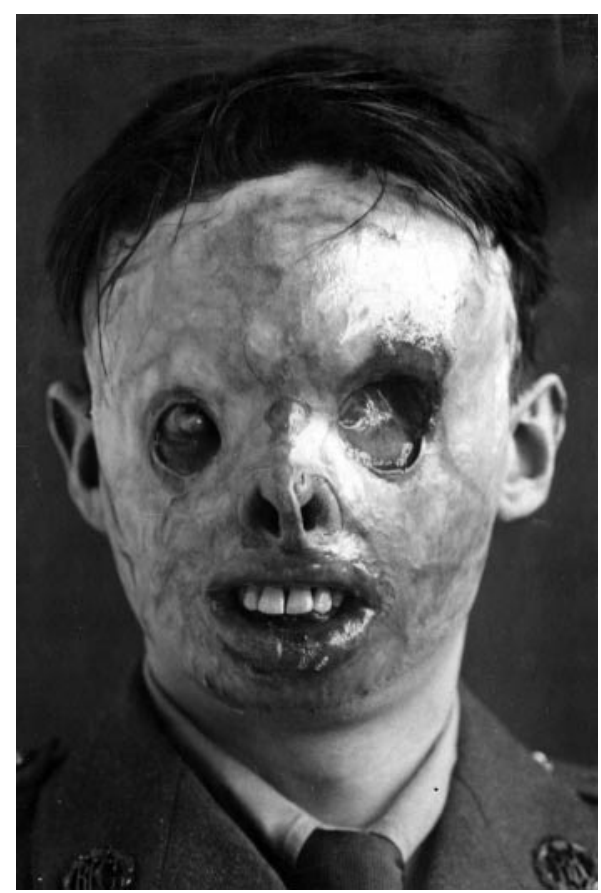

Figure 1: Photograph of patient before surgery, Lumley case file. Courtesy of the Gillies Archives, Queen Mary's Hospital Sidcup.

had 254,405 hits, so either it has been seen by a considerable number of individuals, or there are people - like me - who've returned to it repeatedly, for whatever reason.

Henry Lumley was admitted to the specialist hospital for facial casualties in October 1917. A 2nd Lieutenant in the Royal Flying Corps, Lumley had been wounded on 14 July 1916. By the time he came to Sidcup, he had lived with his injuries for over a year. No further mention is made of the accident in the case notes, but a genealogist working on Project Façade looked up Lumley's service records in The National Archives. ${ }^{9}$ A former operator with the Eastern Telegraph Company, Henry was selected for the RFC's Special Reserve of Officers in April 1916. He never made it out of England though: a letter from the Central Flying School in Upavon, dated 9 August 1916, reveals that the accident happened on the day of his graduation.

The two operations at Sidcup, in November 1917 and February 1918, are documented in detail in the case notes, and revisited in Gillies' 1920 textbook, Plastic Surgery of the Face, which is now out of copyright and freely available online. ${ }^{10}$ A diagram shows

\footnotetext{
${ }^{9}$ The relevant records are: WO 372: Medal Index Card entry; WO 339/57830: Officers' service records; and MH 106/2204: Medical Sheets: Royal Flying Corps, I - O. I am grateful to Paddy Hartley of Project Façade for this information.
}

\footnotetext{
${ }^{10}$ Canadian Libraries' Internet Archive, $<$ http:// www.archive.org/details/plasticsurgeryof00gilluoft $>$, accessed 8 February 2011.
} 


\section{Suzannah Biernoff}

Gillies' ambitious plan to remove the existing scar tissue and raise a large flap of skin from Lumley's chest with pedicle tubes providing a further blood supply to the graft. Despite ongoing complications, the initial signs were encouraging, but by day three after the second operation the graft had developed gangrene. Henry Lumley died twenty-four days later on 11 March 1918. He was twenty-six.

\section{Project Façade versus BioShock}

While I was looking online for images from the Gillies Archives, I came across a discussion forum hosted by $2 \mathrm{~K}$ Games. $2 \mathrm{~K}$ - formerly Irrational Games - are the developers of BioShock, a computer game designed by Ken Levine and released in August 2007. It won the BAFTA for Best Game that year, among a constellation of other awards, and is ranked in the top five Xbox 360 and PlayStation 3 games to date. ${ }^{11}$ For the novice, BioShock is what is known as a first-person shooter, although it is much more besides. This is how the game's marketing department describes the story:

After your plane crashes into icy uncharted waters, you discover a rusted bathysphere and descend into Rapture, a city hidden beneath the sea. Constructed as an idealistic society for a hand-picked group of scientists, artists and industrialists, the idealism is no more.

Now the city is littered with corpses, wildly powerful guardians roam the corridors as little girls loot the dead, and genetically mutated citizens ambush you at every turn. BioShock forces you to question the lengths to which you will go and how much of your humanity you will sacrifice... to save your own life. ${ }^{12}$

The online discussion is headed 'Project Façade vs Bioshock?' and begins on 18 July 2007 , amidst the flurry of publicity just prior to the game's release. ${ }^{13}$ The original posting is simply a set of links: the first takes you to Project Façade, the second to Henry Lumley's photograph, the third to one of the concept drawings for BioShock, and the last two to stills from the game itself. ${ }^{14}$ The debate circles around a series of questions: Did the game's designers use real people (Lumley is not alone) as inspiration for the monstrous inhabitants of Rapture? ${ }^{15}$ Does that matter? Will it change the way you play the game, knowing that the enemy you are shooting, bludgeoning or blowing up is based on someone who was shot, burned or blown up for real? Are there, in other words, ethical limits to artistic 'inspiration', on the one hand, and immersiveness or realism on the other? One has to bear in mind that this is a site for players, who are going to buy and enjoy the game whatever. For them, BioShock's 'creepiness' and moral ambiguity are its greatest virtues.

\footnotetext{
${ }^{11}$ Game Rankings, <http://www.gamerankings. com/>, accessed 8 February 2011. The BioShock II website claims more than 50 Game of the Year awards for the franchise. http://www.2kgames.com/\#/ games/bioshock-2, accessed 2 March 2011.

${ }^{12}<$ http://www.2kgames.com/\#/games/ bioshock>, accessed 26 January 2011.

13 'Project Façade vs BioShock?', <http:// forums.2kgames.com/forums/archive/index.php/ t-1836.html>, accessed 26 January 2011.
}

\footnotetext{
${ }^{14}$ The link to the concept art is now inactive, but the artwork is reproduced in the BioShock players' manual: Doug Walsh, BioShock, Bradygames Signature Series Guide (Indianapolis: DK Publishing, 2007), 51. Examples can also be seen on the BioShock Wiki: <http://bioshock.wikia.com/wiki/Toasty $>$, accessed 8 February 2011.

${ }^{15}$ In Lumley's case there are no known relatives. In order to protect the privacy of the other families, no identifying details have been included here.
} 


\section{Medical Archives and Digital Culture}

\section{The Ethics of Inspiration}

The artists who worked on BioShock are surprisingly open about their sources, given their apparent lack of concern for copyright protocol. In the Making of BioShock DVD, which has been posted on YouTube, Nate Wells (one of the technical artists) admits - slightly uncomfortably - that the Project Façade website provided 'disturbing inspiration' for their splicer artwork. ${ }^{16}$ Of course, artists since the Renaissance have used medical subjects and images for inspiration: from Leonardo da Vinci's grotesques to Francis Bacon's collection of medical textbooks. ${ }^{17}$ When the contents of Bacon's studio in Reece Mews was posthumously catalogued by archaeologists, one of the items that came to light was a chromolithograph of diseased gums that Bacon had torn from a copy of the Atlas-Manuel des maladies de la bouche, a French translation of an 1894 German medical textbook, acquired while Bacon was in Paris in 1927. The gaping mouth of the Atlas-Manuel reappears throughout Bacon's oeuvre, most famously in the central canvas of Three Studies for Figures at the Base of a Crucifixion (1945) and the 'screaming popes' of the 1950s. It cannot have crossed his mind to seek copyright permission. What is the difference between Bacon's fascination with those 'beautiful' diseased mouths - as he described them in a 1966 interview with David Sylvester - and the use of Gillies' case photographs in BioShock $?^{18}$

Is the difference that one is art, the other entertainment? Although the distinction is ultimately unsustainable, it is still widely believed that 'art' is morally beneficial (except perhaps when it is too entertaining) and that computer games are not. In art (it is said) cruelty and violence are sublimated rather than simply enjoyed. There is, however, a more tenable difference, to do with recognition and identity. To begin with, the mouths in the Atlas-Manuel are anonymous - unlike Gillies' patients. We recognise faces and names, and familiar voices, but not (unless you are a dentist or forensic pathologist) teeth or gums. Furthermore, the creative distance between the coloured plate in the textbook and the eventual painting makes recognition impossible: even a dentist would fail to identify Bacon's sources from his operatic deformations of the human. The problem with BioShock is that the splicers are based on identifiable individuals, who - if they were alive - would be entitled to sue for defamation or slander. All of Gillies' patients are now dead, but many live on in the memories of their children and grandchildren. For them, BioShock can only be a perverse transgression of the pledge not to forget.

The past is not just a place of origin: it is an open-ended relationship with a multitude of presents. 'Honor the dead people' is one of the comments posted on the BioShock discussion forum. ${ }^{19}$ Honour the remains of the dead is the implication. This simple

\footnotetext{
${ }^{16}$ Bioshock Making Of - Characters: <http:// www.youtube.com/watch?v=FQ7YT8Ajr0c $>$, accessed 26 January 2011, comments at 5:50. Wells credits Ken Levine with the discovery of Project Façade. The Concept Artist Robb Waters also mentions using 'old mug shots from the 1940s'.

${ }^{17}$ On Leonardo da Vinci's Grotesque Heads, see: Kenneth Clark, Leonardo da Vinci [1939], (repr. Harmondsworth: Penguin, 1989), 120-4; E.H. Gombrich, 'The Grotesque Heads' [1954] in The
}

\author{
Heritage of Apelles, Studies in the Art of the \\ Renaissance, 3 (Oxford: Phaidon, 1976); and Martin \\ Clayton, Leonardo da Vinci: The Divine and the \\ Grotesque, exhibition catalogue (London: Royal \\ Collection Enterprises, 2002). \\ ${ }^{18}$ David Sylvester, The Brutality of Fact: \\ Interviews with Francis Bacon (London: Thames and \\ Hudson, 1987). \\ 19 'Project Façade vs BioShock?', op. cit. (note \\ 13), post by Nias Wolf, 18 July 2007, 10:03 am.
}




\section{Suzannah Biernoff}

comment highlights the ontological complexity of medical records, especially clinical images. The Human Tissue Act protects one version of human being: the individual understood as a sum of his or her body parts. It does this through the legal requirement of consent. The Act is silent, though, on the subject of photography and film. ${ }^{20}$ It seems to me that Lumley's photograph points us towards a more diffuse and less positivistic understanding of personhood than that enshrined in the law: one that would encompass facial likeness as a privileged index of personhood and identity. There can be no moral absolutes from an historical perspective, but if BioShock is ethically problematic - even within the confines of the $2 \mathrm{~K}$ discussion forum - it is because it violates the perception that photographs of people somehow contain or capture their subjects; and that they therefore carry a burden of care.

\section{Acknowledgements}

This research has been made possible by a Wellcome Trust Research Leave Award [No. 082864], granted in 2007 for a project on the corporeal territories of war.

\footnotetext{
${ }^{20}$ Interestingly, the Science Museum in London does take account of 'cultural objections or taboos surrounding the representation of remains, as well as the display of remains themselves.' However, this sensitivity extends only to images of non-European
}

\author{
remains: <http://www.sciencemuseum.org.uk/ \\ about_us/about_the_museum/collections/ \\ human_remains/human_remains_policy.aspx $>$, \\ accessed 8 February 2011.
}

